\title{
Historein
}

Vol 14, No 1 (2014)

On the Edge of History and Philosophy

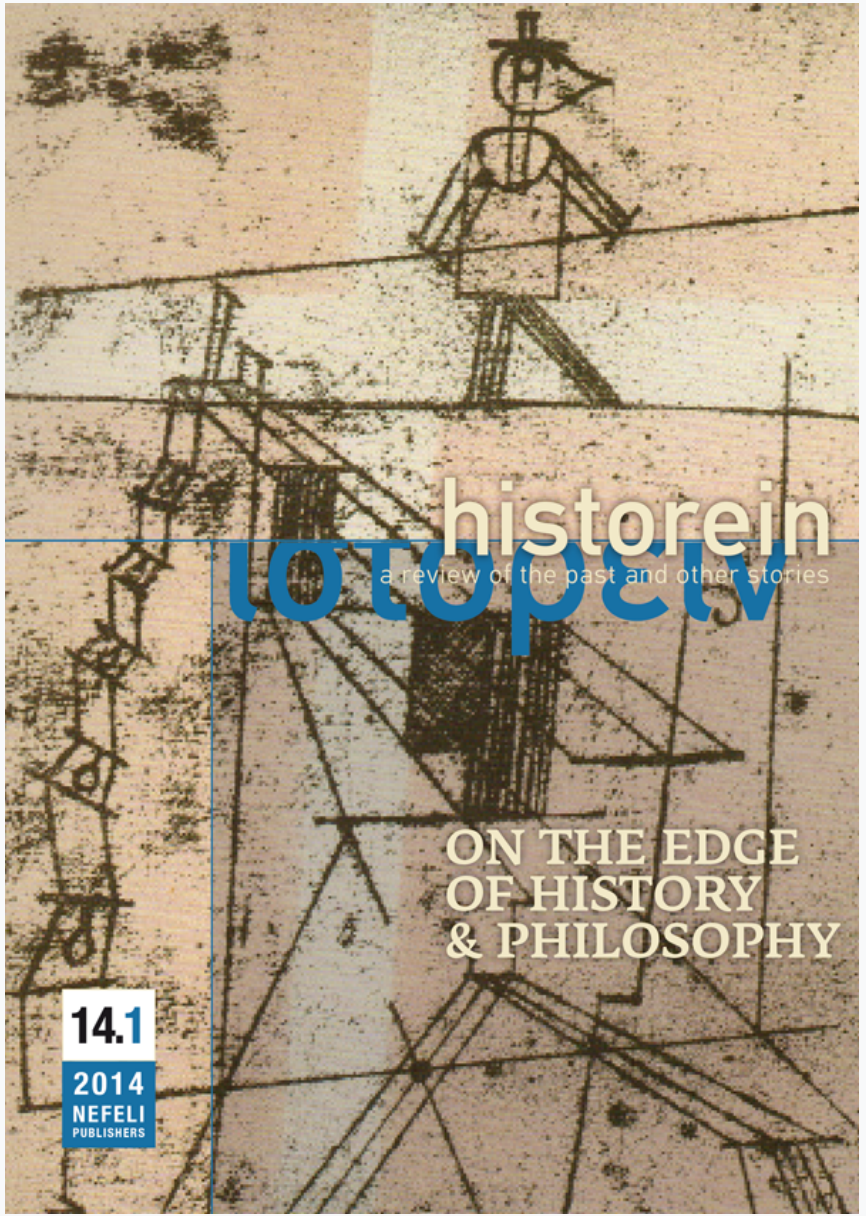

\section{Review of C. Ingrao's "Believe and Destroy": Intellectuals in the SS War Machine}

Anna Maria Droumpouki

doi: $10.12681 /$ historein.245

Copyright @ 92014 , Anna Maria Droumpouki

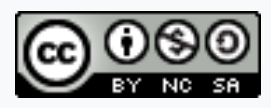

This work is licensed under a Creative Commons Attribution-NonCommercialShareAlike 4.0.

\section{To cite this article:}

Droumpouki, A. M. (2013). Review of C. Ingrao's "Believe and Destroy": Intellectuals in the SS War Machine. Historein, 14(1), 108-111. https://doi.org/10.12681/historein.245 
vious character, but the latent parameters, of a multidimensional, sometimes "hidden" and widely unspoken histoire that still influences several aspects of Greek discourse, be it ethical, political, scientific or everyday conversation. Furthermore, the study of physical anthropology, eugenics and race provides the research community with some quite useful analytical tools to critically question the idea of being able to flawlessly define or easily design society along "pure" biological or medical lines.

To those living in a society that is experiencing an immense attack on social and personal rights at a variety of levels and which is facing the political uprising of the most reactionary, ultraconservative, dangerous and violent aspects of racial ideology and eugenic hygiene practices, this study offers a deep understanding of the foundations of this political rhetoric. As Walter Benjamin once wrote, "Truth is not a matter of exposure which destroys the secret, but a revelation that does justice to it".

\section{Christian Ingrao}

\section{Believe and Destroy: Intellectuals in the SS War Machine}

\section{Cambridge: Polity, 2013. xiv +399 pp}

\section{Anna Maria Droumpouki}

University of Athens

Is the intellectual elite capable of committing terrible crimes? Can an intellectual be part of a genocidal operation, a machinery of death? Why did a sample of 80 German academics, with high profiles and, in some cases, brilliant minds, join the repressive bodies of the Third Reich, especially the Security Service (SD) and the Nazi party's elite protection unit, the SS? How could they theorise and plan the extermination of 20 million individuals of allegedly "inferior" races? Most of them became members of the paramilitary death squads known as the Einsatzgruppen and participated in the slaughter of over a million people. The Einsatzgruppen were responsible for mass killings, primarily by shooting, and carried out operations that in cases lasted for days, such as the massacre at Babi Yar, one of the largest massacres in the history of the Holocaust (29-30September 1941). How can we interpret the mass participation of these people in the genocidal machinery of the Nazis?

In this book, Christian Ingrao tells the gripping story of 80 intellectuals who were young (barely in their 30s), clever and cultivated, and analyses the complicated mechanisms of their political commitment. This is a history of the executioners, not the victims. What is most interesting is the fact that Ingrao analyses Nazism as a system of beliefs. His explanation for the intellectual activism of these people is debatable; the interaction of knowledge, activism and levels of cultural sophistication 
helped to formulate the specific character of these Nazi intellectuals, who began their political engagement in student fraternities, sporting clubs and other organisations in the early 1930s. After their studies and their incorporation into both the SD and SS, they took over the scientific disciplines and nazified them. This nazification of knowledge indicates the importance of academic knowledge in the formation of the ideological world of the Third Reich, even though that knowledge was distorted and falsified.

After reading this work, we must refocus our attention on books such as Jonathan Littell's The Kindly Ones, a literary phenomenon that has the same theme as Ingrao's book, even though its basis is fictional. Littell sought to focus on the mindset of an executioner and on the origins of state murder, showing how "ordinary men" could make decisions that led to the massacres of the so-called "final solution". Littell claims he created the character of an SS executioner, Max Aue, by imagining what he would have done and how he would have behaved had he grown up in Nazi Germany, into different circumstances in a different time. Littell portrays his main character as a man no different to any other, who states "I am a man like other men, I am a man like you."

Ingrao does the same. He gets under the skin of the murderers in trying to answer the question: does genocide have a bureaucratic nature? Is the famous argument of Adolf Eichmann that they "had no other choices than to follow orders" still valid? This is not a new discussion. Recent scholarship has shown that members of the Einsatzgruppen who refused execution duties were not punished. The truth is that, although many found shooting unarmed Jews, women and children highly disagreeable, there was no great desire to refuse to do their "duty". There was a belief in the ne- cessity of their task and initial hesitations were soon overcome. In the end, killing was considered a job like any other. Hannah Arendt, in her famous analysis of the Eichmann trial, sees the perpetrators as blind bureaucrats whose obedience was a combination of careerism and insensitivity. We could argue that Ingrao doesn't reject this analysis, but he gives an analytical account to explain the actions of the Nazi intellectuals. In contrast to previous scholarship, he investigates the perpetrators' action by shedding light on the killing procedure. He interprets the genocidal slaughter by following the life paths and careers of these people from early on, and by placing these practices within a general historical context beginning with the end of the first world war.

These intellectuals, scientists and historians formulated theories and doctrines such as the "Nordic doctrine of races", a racial utopia where Germans were at the top of the racial hierarchy. A new kind of racial anthropology was born, and within a context that Ingrao describes as the "nazification of minds", new ideologies and ideas emerged in order to help the ultimate cause, the victory of the "fatherland", and resolve the existential crisis that German society faced since the beginning of the Weimar republic. The SS intellectuals constructed an image of Jewishness which was explicitly repellent; they wanted to portray the Jews as dangerous enemies of the state, with the effect that antisemitic feelings were mobilised within German society from very early on. Therefore, these people played a decisive role in it, by forming an ideological apparatus that led to the consolidation of Judeophobia. As the writer aptly puts it, "work in the SD was essentially a matter of finding the right arguments".

Why did these people join the Nazi party, the SS and the SD? Were they motivated by pure opportunism or authentic activist feelings that 
derived from an ideology that was formed slowly during the interwar years? Were they functionaries or careerists? Did the group of SS officers examined really hold fascist beliefs, or did they go along with the Führer primarily for the sake of their own careers? Ingrao states that, for these men, the party was a symbol of their activism; they were committed supporters from very early on. We can't give any simplistic answer about the reasons for their recruitment to the Nazi party. Many of these men joined in the months following the Machtergreifung, the seizure of power on 30 January 1933 . What is more interesting is that the party, in order to preserve its activist dimension, stopped recruiting between 1934 and 1937-38.

We have to rethink the terms "ambition", "careerism", and "obedience", which is what Ingrao does, avoiding the existing dichotomic schemes of historiography on the second world war. The horrific duties of SS intellectuals on the eastern front were carried out without any obvious psychological effects or potential emotional impact, some exceptions aside. The tale that is narrated is sometimes savage. It's not only the pity and the horror of the war, but also the description of the barbarity. The Einsatzgruppen were engaged in a utopian war on the eastern front, which involved not only the radicalisation of repressive practices, the liquidation of entire populations, but first and foremost the implementation of genocidal violence. The unimaginable violence exerted is described in the book, particularly the case of a Vienna police officer, Walter Mattner, who wrote to his wife on 5 October 1941 that he took part in the liquidation of the Moghilev ghetto and that he even shot babies: "The death we gave them was nice and quick. The babies flew in great arcs and we shot them to pieces in the air before they fell into the ditch and the water. l'd never seen so much blood, filth, flesh." This genocidal violence was also committed by men who displayed the characteristics of educated intellectuals. A violent and sadistic universe had become a daily routine for these men, who, as Ingrao writes, became accustomed to a radicalisation of violent practices, meaning familiarity with violence, until the end of the war. The author quotes from letters sent by soldiers on the eastern front, the main "theatre" of violence. As one soldier from the sixth army wrote to his parents: "The Jews are beaten to death with sticks and spades. Up to now we have dispatched into the hereafter about a thousand Jews, but that's still too few, given what they have done." This savage description was provided with no regrets; these soldiers were ideologically convinced that these acts were necessary means of defence against the "barbarians" of the east.

German troops, Ingrao argues, "entered Russia in an advanced state of psychosis". It is clear that he is not interested in the psychology of these people; he sees violence as a codified language, as collective ritual forms that helps in fighting the enemy and boosts the soldiers psychologically to endure this brutal and savage process of executions, even when it involved "sticks and spades". But what is missing here is a deep immersion into the souls, thoughts and beliefs of these executioners. How do they get accustomed to this violence? Could it be pure professionalism, or the propaganda against the enemy, that affected them so deeply? Or the political activism and belief in the Nazi party and its ideology? A result of the fervent atmosphere of the times or simply obedience to orders? Ingrao compellingly analyses the procedures of killing, the series of rituals that were chosen (the mass shootings of victims in the back of the head as they stood in front of a ditch), in other words the "cultural construction of violence" that even included the extermination of children. Did this habitual 
sadistic violence even provoke pleasure? And were intellectuals integral to this procedure or not? The writer attempts to give an answer: "SS intellectuals did indeed play a crucial role ... [in] providing the perpetrators with doctrinal justification. As a result of their very presence in the Nazi killing squads and their involvement in the acts of murder, they were right at the forefront of a confrontation with genocidal violence."

Even though the writer argues that this violence was more a matter of fervour than political and activist calculation, ultimately we are not provided with a general picture of this "social anthropology of Nazi emotions", to use Ingrao's term, the mental processes of these intellectuals that exerted this paroxysmal violence. It cannot always have been an issue of defending against the "barbarians" (communists or Jews) or of violence as a precondition for the Germanisation of new territories. Here we have to immerse ourselves into mentalities, collectivities and the psychology of these intellectuals. This book lacks an analysis of the characters, the people, and the emotional and psychological impact that this violence had on them. Even though Ingrao discusses the causes of this brutal behaviour extensively and eloquently, historians require an understanding of the key psychological types, an understanding of the psychology of people who were trained or volunteered to participate in atrocities which are described in a diffuse way in this book. The mindset of the perpetrators and their motivation for killing is the key point of Ingrao's book, but at the end the reader may be left with the impression that the Holocaust, the genocide and all wartime atrocities remain inexplicable. This is justified to some degree; human nature is complicated and indefinable. The important question how "ordinary men" become killers remains unanswered. After all, hard ques- tions have no easy answers, and this book poses complex philosophical questions.

This study is a collective portrait of a generation of perpetrators, responsible for the suffering of millions of people, and covers the same ground as Christopher Browning's Ordinary Men: Reserve Police Battalion 101 and Daniel Goldhagen's Hitler's Willing Executioners. However, Ingrao doesn't follow any of the arguments from these books; he is not walking the same path. The intellectuals don't kill out of a basic obedience to rules and duties; neither do they execute out of bloodlust. The writer argues that the "final solution" was a result of many factors, first and foremost the radicalisation of the German state that started at the end of the first world war. He doesn't exaggerate like Goldhagen, who interpreted the Holocaust as a result of the cultural norm of "eliminationist antisemitism" that existed in German society for centuries. He is very careful in his explanations, eschewing provocative arguments and simplistic answers. Schematic views don't interest this writer, who has dived deep into the archives and tried to explain the Holocaust historically and culturally. This book does not weaken the importance of discourse for the actions of the perpetrators during the war; on the contrary, it is strengthened. But we still have a long way to go in order to comprehend the psychology of mass murderers, the dark sides of the tens of thousands of people who seemed "normal" but pulled the triggers remorselessly during the war. 